\title{
TWO WASHINGTON LETTERS
}

\author{
BY GEORGE P. SCHMIDT
}

Several years ago The Journal published an article by Dr. Schmidt on the Washington letters at that time in the Library's collections. Since then other items have been added, two of which are here described. Dr. Schmidt is chairman of the Department of History, New Jersey College for Women.

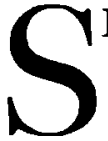

INCE the time that the Library's collection of Washington letters was first mentioned in The Journal (Vol. II, No. 2) two additional Washington items have come into its possession. The first is a military order, of June 20,1777 , from headquarters at Middle Brook [New Jersey], directed to Brigadier Generals McDougall and Glover. The order does not appear in the Fitzpatrick bi-centennial edition of Washington's writings and presumably has never been published before; but another manuscript version of it is in the Washington papers of the Library of Congress. ${ }^{1}$ It is likely that neither version is the letter which was actually sent. The Rutgers copy, in the handwriting of Tench Tilghman, is not addressed but merely labeled on the reverse as "Gen'l Washington's Letter 2oth June I 777." It does, however, carry Washington's signature, whereas the Library of Congress copy is unsigned. The latter, furthermore, though addressed "To Generals McDougall \& Glover" contains corrections, words struck out, and phrases inserted above the line, all of which would suggest a first draft and not a fair copy. It was apparently written by Hamilton.

The occasion for writing this order was a sudden and inexplicable withdrawal of General Howe's forces in central New Jersey. It was the summer of the Burgoyne campaign; the latter was known to be descending from Canada, and Washington fully expected Howe to make the logical move up the Hudson, join forces with Burgoyne and cut the country in two. But Howe did not act as expected; instead, after several feints into New Jersey, he embarked with his army for the Delaware Capes and Philadelphia, leaving Burgoyne in the lurch. Without going into the reasons for this peculiar strategy,

${ }^{1}$ In a letter to the President of Congress of the same date Washington includes the substance of the order and expresses keen satisfaction at Howe's withdrawal. John C. Fitzpatrick, The Writings of George Washington 1745-1799 (Washington, Government Printing Office, 1931 et seq.), vol. viII, p. 269. 
the motive and purpose of which baffled historians for years and sent them rummaging in the Germain and Clinton papers, we can readily understand why Washington would find Howe's conduct "puzzling, and embarrassing beyond measure." While giving evidence of this perplexity, the Rutgers letter is at the same time an illustration of the Commander-in-Chief's extreme watchfulness and determination to provide for every contingency and to leave nothing to chance. Had he not been so careful he might easily have lost the war then and there, for his army had shrunk in the previous winter to a pitiful three thousand effectives, and Howe's feint through Brunswick to Somerset was probably designed to draw this little force down from the Watchung Hills and destroy it in the plain. If this was the purpose, Washington cleverly evaded the trap. ${ }^{2}$

The other item which the Library has acquired, of no great significance in itself, calls attention to one of the embarrassing consequences of the French alliance: the need of placing, and placating, the numerous European soldiers of fortune who came over to help win American independence and sometimes to advance their own interests as well. It is a routine character endorsement for a French volunteer officer, probably one of many that Washington had to write. Fitzpatrick does not have it but refers to it in a note as existing in the Library of Congress collection. ${ }^{3}$ The accompanying certificate, in French, over Lafayette's signature and presumably written by him, is not found in Gottschalk's The Letters Of Lafayette To Washington 1777 to $1799^{4}$ and, so far as the present writer knows, has never seen print.

Louis Pierre, Marquis de Vienne (1746-1825?), one of the French officers recommended to Washington by Lafayette, had requested a furlough to return to France on personal business, and this request was the occasion for the two certificates of character. Vienne was in Boston at the time. One wonders whether his desire to return to France was in any way connected with the difficulties between French and Bostonians in the fall of $\mathrm{I} 778$. It was after the unsuccessful expedition against Newport, where the fleet of Comte D'Estaing, which had participated in the attack, had been so badly dam-

\footnotetext{
2 Rupert Hughes, George Washington The Savior Of The States (New York, 1930), chs. I4 and 15, passim.

${ }^{3}$ Fitzpatrick, vol. XII, p. 515, note.

${ }^{4}$ New York, 1944.
} 
aged by storms that it was forced to put into Boston for refitting. Feeling against the French ran high in Boston, and French sailors were killed in the streets. ${ }^{5}$ Even Lafayette, who had been in command of the land forces attacking Newport, hesitated to go to Boston until assured that he might appear there "with all safety."

Washington forwarded Vienne's request to the President of Congress with a covering letter suggesting a leave of eighteen months. ${ }^{7}$ The Marquis returned to France and remained there. Never prominent among the French volunteers, he seems to have lost whatever favor he may have had with Lafayette, for when writing to Washington after the close of the war about the claims of various French military and naval officers to membership in the Society of the Cincinnati, Lafayette dismisses the Marquis' petition for membership by pointing out that he "has not the shadow of a title, and if such were admitted, the pretensions would be numberless, and come from very disagreeable persons."

The letter of Washington to Brigadier McDougall and Glover follows.

Head Quarters Middle Brook $20^{\text {th }}$ June

1777

SIR,

The Enemy decamped, the night before last, \& have returned to their former position from Amboy to Brunswick. This appears to have been in consequence of a sudden resolution, as they had been employ'd in raising a chain of Redoubts from Sommerset to Brunswick; which they wou'd not have done, had they at first intended to abandon their new Ground in so short a time.-What may have determined them to change their plan it is hard to tell; - whether they might have been alarmed by the animation among the People, which brought them together in considerable numbers \& disappointed in the movements they may have expected us to make, thence concluding their design impracticable; - or whether they may have an operation against some other Quarter in view, the event must show.-In the mean time, I think it necessary to be upon our Guard against any sudden expedition up the North River, $\&$ therefore desire

${ }^{5}$ Ibid., preface, p. xii.

7 Fitzpatrick, vol. XII, p. 5 I4.
6 Ibid., p. 68.

${ }^{8}$ Gottschalk, p. 297. 
you will if you have advanc'd any distance from Peekskill halt where you are \& proceed no further.--if you are near that Post return to it, or if you have not cross'd the River you are of course to continue where you are.

I am Sir

Your most Obet. Servant

G. Washington

Certificates concerning the Marquis de Vienne:

I certify, that the Marquis De Vienne served, some time, in the army, under my immediate command, in character of Volunteer, during which, his conduct was always such as became an Officer and Gentleman; having embraced every occasion, his situation offered, to give proofs of his zeal and bravery- $\mathrm{He}$ received an appointment by brevet to the rank of Colonel in the Army of the United States the fifteenth of July last.

Head Quarters

G. Washington.

Fredericksburg Sept $29^{\text {th }} 1778$

(2)

Je certifie que monsieur le Marquis de Vienne Colonel au service des états unis de l'amerique, a joint l'armée de son ex. $\mathrm{mr}$ le general Washington au mois de juin dernier; qu'il a servi avec moi jusqu'a ce jour et s'est principallement trouvé à la bataille de Montmouth, et à la descente de nos troupes sur Rhode island, et que sa conduite militaire a été digne du nom qu'il porte et de toutes les autres qualités personelles. Fait à Bristol près Rhode island le 23 Septembre 1778

LAFAYETTE 